\title{
Quality and acceptability of burger patty as influenced by the levels of mung bean (Vigna radiata) flour as meat substitute
}

\author{
Clarita E. Morbos" ${ }^{1 *}$ Melogen Bandalan', Jenalyn M. Gonzaga', Eliza C. \\ Cabugawan' and Lorina A. Galvez ${ }^{2}$
}

\begin{abstract}
This study was undertaken to evaluate the effects of different levels of mung bean flour as meat substitute on the sensory quality of burger patties, determine the physicochemical properties, and compare production costs of burger patties containing varying levels of mung bean flour. The mung bean flour was prepared by drying and grinding the mung bean seeds. Five levels $(10,20,30,40,50 \%)$ of mung bean was used as replacement for lean meat in the formulation with $0 \%$ mung bean flour used as control. The physicochemical composition of the patties was determined. The sensory attributes were evaluated by thirty semi-trained panelists. Data on physicochemical characteristics were analyzed by one-way analysis of variance (ANOVA) while quality description of the sensory attributes were evaluated in combination with the 9-Point Hedonic Scale and the mean acceptability ratings were analyzed using Friedman Test.

Thirty percent mung bean flour substitute is possible to the production of burger patty without significant effect on the sensory attributes, and the burger patty is comparable to the all-meat control. However, proximate composition in terms of crude protein and fat/ether extract contents were comparable to the control only up to $20 \%$ level of mung bean powder substitution. Thickness expansion was greatest at $20 \%$ substitution, but diameter shrinkage and cooking loss were minimal at $30 \%$ and even up to $50 \%$ substitution, consequently increasing the cooking yield. Production costs decreased with increasing substitution level of mung bean flour in the formulation. Across all parameters, the optimum level of mung bean flour appears to be at $30 \%$ substitution of meat in the burger patty.
\end{abstract}

Keywords: Burger patties, mung bean flour as meat substitute, sensory and quality

\footnotetext{
' Department of Agriculture, College of Agriculture and Allied Sciences, Eastern Samar State University Salcedo, Salcedo, Eastern Samar

${ }^{2}$ Department of Food Science and Technology, College of Agriculture and Food Science, Visayas State University, Visca, Baybay City, Leyte
}

*Corresponding Author. Address: Department of Agriculture, College of Agriculture and Allied Sciences, Eastern Samar State University - Salcedo, Salcedo, Eastern Samar; Email: essuclarita morbos@gmail.com

DOI: $10.32945 /$ atr 4119.2019 
Quality and acceptability of burger patty

\section{INTRODUCTION}

\section{Nature and Importance of the Study}

In today's consuming world, there is an increasing trend towards conveniently derived foods that appear to fit the increasingly busy lives of people. Among these ready-to-serve foods, hamburger had been listed in the higher end as this is readily accepted by consumers, thus, it is becoming popular (Egbert et al 1991, Menkhaus et al 1993). Burger patties used in hamburgers are usually prepared from pork and beef, although some burger patties can be versatile in form suitable to different food patterns and cooking styles with several types of seasoning and flavorings. These are easy to prepare, take less time to cook, have unique flavor and taste, and can be served to a large number of customers in a relatively short period of time. Thus burger patties come under the category of fast foods. However, the use of these meat-based patties is limited only to meat-consuming customers, and the cost restricts its market only among the low-income sectors of society. Thus, modifications of its formulation while keeping the sensory attributes at acceptable limits pose a great challenge to the food processors and as such, the use of lowcost nonmeat protein substitute is an important area to explore.

Nonmeat proteins from a variety of plant sources such as soy protein (Gujral et al 2002), common bean flour (Dzudie et al 2002), and corn flour (Serdarouglu \& Degirmencioglu 2004) have been used as both extenders and binders in comminuted meat products. Nonmeat ingredients have also been used as emulsifiers for improving texture and appearance, but they have to be assessed in terms of stability, yield, textural palatability and cost (Roberts 1974). Legumes are considered excellent sources of good quality protein, which may offer great potential (Aruna \& Prakash 1993, Liu 2000, Khalid et al 2003). Since legume seeds are not only sources of protein but also complex carbohydrates and dietary fiber, there is a growing interest worldwide in using legumes as meat extenders or meat substitutes (Khalil 2006).

Among the legumes, mung bean has a greater potential as it is not only an excellent source of high-quality protein, but is also readily available, being widely grown in Eastern Visayas, and is the cheapest among plant protein sources. While ground mung bean is used as a meat substitute alone or in combination with other ingredients in many food products, findings on the use of mung bean flour as substitute in burger patties are still anecdotal. This study was conducted to evaluate mung bean flour as meat extender or substitute on the quality characteristics and consumer acceptability of burger patties. It aimed to evaluate the effects of different levels of mung bean flour as meat substitute on the sensory characteristics and acceptability of burger patties, characterize the burger patties added with different levels of mung bean flour in terms of physicochemical properties and nutrient composition, and compare production costs of burger patties containing varying levels of mung bean flour as substitute for meat. 


\section{MATERIALS AND METHODS}

\section{Ingredients Preparation}

Ingredients included seeds of mung bean, pork meat and other ingredients, such as salt, phosphate, egg, powdered milk, corn starch, sugar, monosodium glutamate, black pepper and onions. Mung bean seeds were ground into flour using a conventional mill and the flour was placed in a polyethylene or plastic bag. Fresh lean pork was chopped and ground using an electric grinder. The minced meat was placed in a plastic container and chilled overnight.

\section{Burger Patties Preparation}

The burger patty was prepared at six inclusion levels of mung bean flour (Table 1). The minced meat and mung bean flour were apportioned into the six groups of five hundred grams mixture for each treatment. All other ingredients such as the curing mix ( $1 / 2$ tbsp salt, $1 / 2$ tsp phosphate, $1 / 8 \mathrm{C}$ water), ingredients binder ( $1 / 4 \mathrm{C}$ water, 1 pc egg, $1 / 8$ c powdered milk, $1 / 8$ c cornstarch) and seasonings ( $1 / 2$ tbsp sugar, $1 / 4$ tsp monosodium glutamate (MSG), $1 / 4$ tbsp ground black pepper, $1 / 2$ tbsp finely ground garlic, $1 / 4 \mathrm{C}$ finely ground onions) were set at constant amount and mixed together before incorporating them into the various treatments. The minced meat was mixed thoroughly with the curing mixture; then, binder was added to form a tacky mixture. The seasonings were added and mixed until well-blended, and the mixture was chilled for 1-2 hours to attain firm patties. The patties were molded manually using a cylindrical molder to produce uniform shape and weight of $45 \mathrm{~g}$ each. Then, these were individually wrapped with wax paper (Figure 1), placed in cylindrical plastic container, labeled and kept frozen for evaluation.

Table 1. Experimental treatments of burger patty with mungbean flour

\begin{tabular}{ccc}
\hline Treatments & Meat Unit (\%) & Mungbean flour level (\% w/w) \\
\hline 1 & 100 & 0 \\
2 & 90 & 10 \\
3 & 80 & 20 \\
4 & 70 & 30 \\
5 & 60 & 40 \\
6 & 50 & 50 \\
\hline
\end{tabular}


Quality and acceptability of burger patty

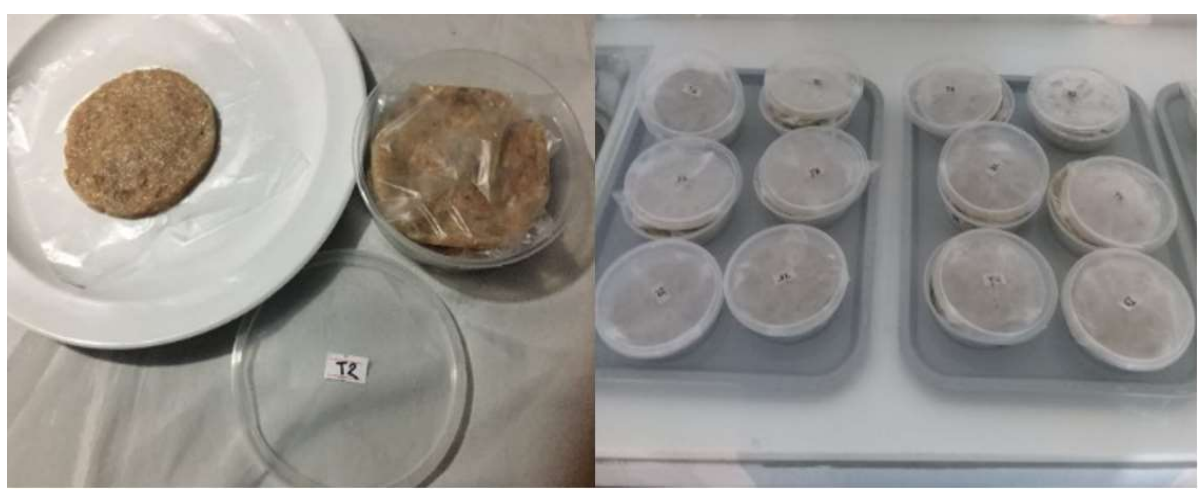

Figure 1. Molding and packing of burger patty

\section{Experimental Setup}

The six experimental treatments were arranged following a Complete Randomized Design (CRD) with six replicates.

\section{Frying of patties}

The patties were fried in a lightly oiled pan over medium heat until both sides got a golden brown color. Frying was done 5-7 minutes per side or until the center part of the patty was cooked.

The weight of the burger patty was recorded before and after frying. The cooking yield was calculated and expressed as percentage by a formula:

Cooking yield percentage $=\frac{\text { Weight of cooked burger patties }}{\text { Weight of raw burger patties }} \times 100$

\section{Product Evaluation}

Sensory evaluations were carried out to determine the color, aroma, flavor, taste, intactness, texture and overall acceptability of the products employing semitrained panelists composed of graduate and undergraduate Food Technology students. The products were sliced into uniform sizes $\left(2 \mathrm{~cm}^{2}\right)$ and placed in coded plates (Figure 2) and presented to the 30 semi-trained panelists. 
Morbos et al

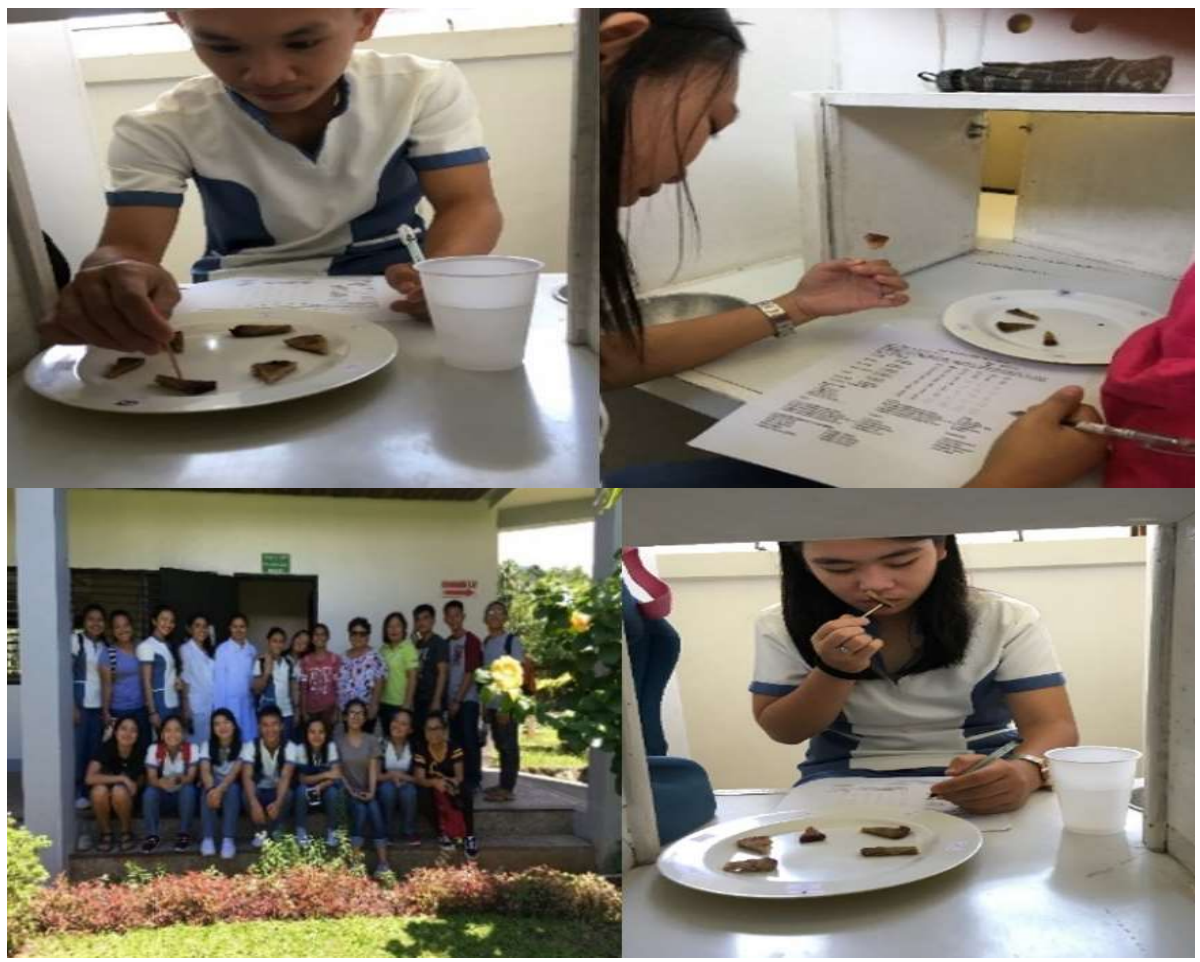

Figure 2. Sensory panelists (Food Technology students)

The sensory attributes of the samples were evaluated using quality scoring in combination with the 9-Point Hedonic scale. Description of the product in terms of color, aroma, flavor, taste, intactness and texture was rated with the scores that ranged from 1 to 5 following their corresponding category. Acceptability of the product was rated using the 9-Point Hedonic scale which ranged from 1 to 9 , where 9 is the highest and 1 is the lowest as shown in the scoresheet. Each panelist was provided with a glass of water to rinse their mouth every after sample testing.

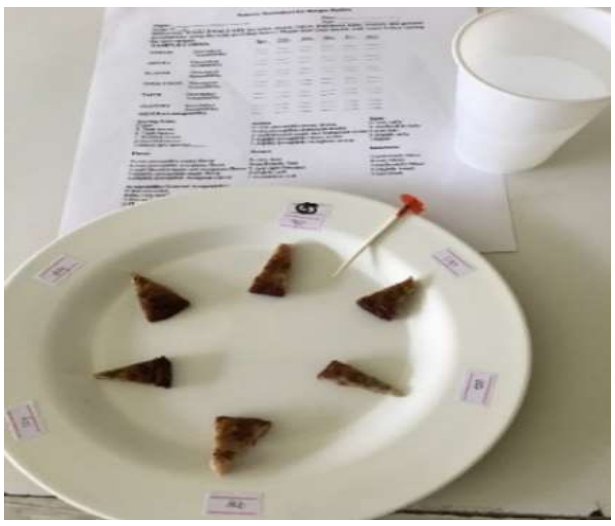

Figure 3. Scoresheet and the coded plate with product for sensory evaluation 
Quality and acceptability of burger patty

\section{Physicochemical Analysis}

Proximate Composition of Burger Patty. The proximate composition of cooked burger patties was analyzed following the method set by Association of Official Analytical Chemist. Moisture content was determined using the air oven drying method, crude protein was analyzed using the Kjeldahl method, and crude fat determination was done following the Soxhlet method set by Association of Official Analytical Chemist (AOAC 1985).

Weight Loss and Recovery of a Patty. Weight loss and recovery of a patty were determined by getting the weight of the raw and cooked patty. These were computed using the formula:

$$
\begin{aligned}
& \% \text { Recovery }=\frac{\text { weight after cooking }}{\text { Weight before cooking }} \times 100 \\
& \% \text { Loss }=\frac{\text { weight before cooking }- \text { weight after cooking }}{\text { Weight before cooking }} \times 100
\end{aligned}
$$

Diameter Shrinkage. The diameter of patties was measured using a Vernier caliper $(\mathrm{mm})$ (Figure 4). Diameter shrinkage was calculated by the differences in diameter between uncooked and cooked burgers, divided by the diameter of uncooked burger. Percent diameter shrinkage was calculated following the formula:

$$
\% \text { diameter shrinkage }=\frac{\text { diameter before cooking }- \text { diameter after cooking }}{\text { diameter before cooking }} \times 100
$$

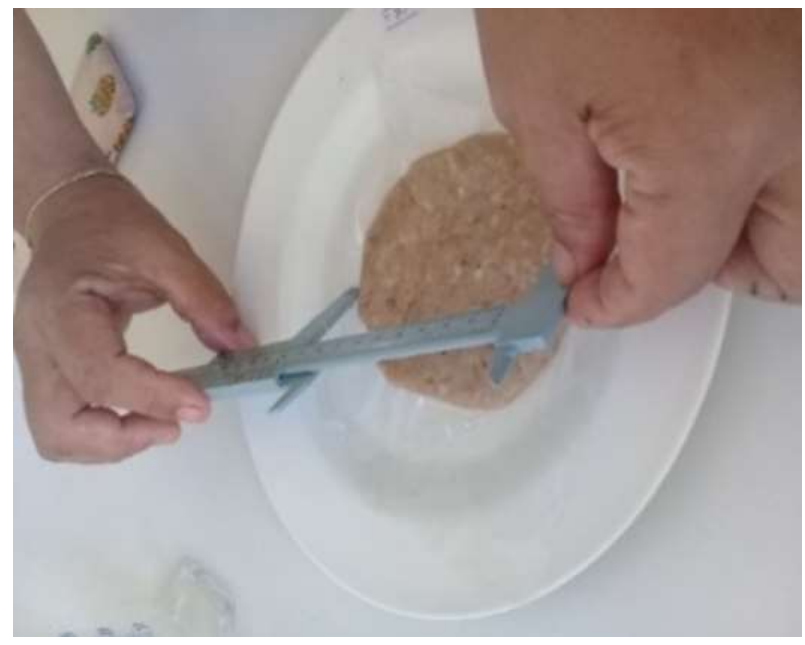

Figure 4. Measuring the diameter of burger patty 
Thickness expansion. Thickness of patty was measured using a vernier caliper (mm) (Figure 5). Thickness expansion was calculated by the differences in thickness between uncooked and cooked burgers, divided by the thickness of uncooked burger. Percent thickness expansion was determined following the

$$
\% \text { thickness expansion }=\frac{\text { thickness after cooking }- \text { thickness before cooking }}{\text { thickness before cooking }} \times 100
$$

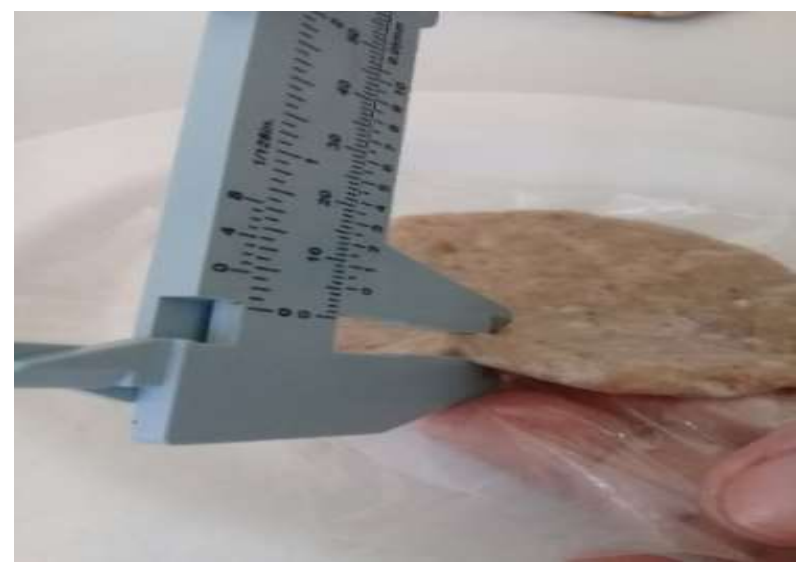

Figure 5. Measuring the thickness of burger patty

Oil Absorption. Oil absorbed by the patty was measured using a graduated cylinder (Figure 6). It was calculated by the differences in oil between before frying and after frying, divided by the oil before frying. Percent oil absorbed was determined following the formula:

$\%$ Oil Absorption $=\frac{\text { Oil before frying }- \text { Oil after frying }}{\text { Oil after frying }} \times 100$

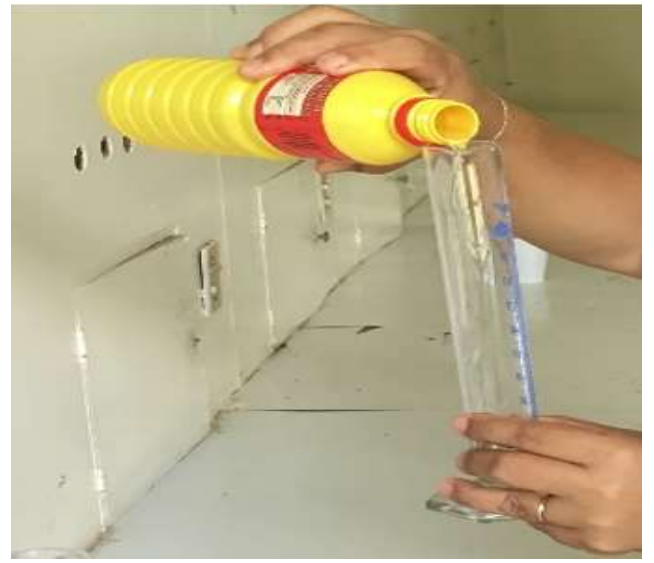

Figure 6. Measuring of oil used before and after frying the patty 
Quality and acceptability of burger patty

\section{Production Cost}

Production cost was determined by recording all expenses incurred for all treatments in producing burger patties added with mung bean.

\section{Statistical Analysis}

Data in sensory evaluation, physicochemical analysis, and proximate analysis were subjected to analysis of variance (ANOVA) following completely randomized design (CRD) to determine treatment effects. Differences in treatment means were compared using the Post- hoc analysis using the Statistical Analytical Software (SAS) and Statistica.

\section{RESULTS AND DISCUSSION}

\section{Sensory Characteristics and Acceptability of Burger Patties}

Sensory evaluation is a very important tool in the evaluation of meat and meat products. Sensory attributes are the basis for the consumer acceptance towards the developed burger patty. Data in Table $2 a$ and $2 b$ indicate the sensory evaluation (color, aroma, taste, texture, flavor, intactness and overall acceptability) of burger patty as influenced by the levels $(0,10,20,30,40$ and $50 \%)$ of mung bean flour as meat substitute. Results showed that there were significant differences $(P<0.05)$ in color, taste, texture and overall acceptability, but no significant differences $(P>0.05)$ in aroma and intactness of all treatments evaluated.

\section{Color}

Color is an important attribute especially in meat and meat products. It often serves as a visual and initial factor in accepting or testing products. This provides the first impression whether or not to accept the product. Table 2a shows the color characteristics of the different burger patties (treatments). According to the panelists, the color description of burger patty was found between light brown to reddish brown, visually shown in Figure 7 . At low levels $(0,10$ and $20 \%$ ) of mung bean flour, the general color of the patty was light brown. On the other hand, with higher levels (30, 40 and 50\%) of mung bean flour, reddish brown color was perceived. The browning of the crust of the patty is more dependent on the amount of heat applied and length of time of exposure to heat. This means that frying temperature influences color development of the patty crust. 


\begin{tabular}{|c|c|c|c|c|c|c|}
\hline \multirow{3}{*}{ Treatment } & \multicolumn{6}{|c|}{ Attributes } \\
\hline & \multicolumn{2}{|c|}{ Color } & \multicolumn{2}{|c|}{ Aroma } & \multicolumn{2}{|c|}{ Flavor } \\
\hline & Description & Acceptability & Description. & Acceptability & Description & Acceptability \\
\hline $\begin{array}{l}\mathrm{T}_{1}-0 \% \\
\text { Mung bean } \\
\text { Flour }\end{array}$ & Light brown & $8.07^{\mathrm{ab}}$ & $\begin{array}{l}\text { Slightly } \\
\text { perceptible } \\
\text { mung bean }\end{array}$ & $8.20^{\mathrm{a}}$ & $\begin{array}{l}\text { Slightly } \\
\text { perceptible } \\
\text { mung bean }\end{array}$ & $8.17^{a}$ \\
\hline $\begin{array}{l}\mathrm{T}_{2}-10 \% \\
\mathrm{MF}\end{array}$ & $\begin{array}{l}\text { Light } \\
\text { brown }\end{array}$ & $8.23^{\mathrm{a}}$ & $\begin{array}{l}\text { Very perceptible } \\
\text { mung bean }\end{array}$ & $8.13^{\mathrm{a}}$ & $\begin{array}{l}\text { Very perceptible } \\
\text { mung bean }\end{array}$ & $8.13^{\mathrm{a}}$ \\
\hline $\begin{array}{l}\mathrm{T}_{3}-20 \% \\
\mathrm{MF}\end{array}$ & Light brown & $8.07^{\mathrm{ab}}$ & $\begin{array}{l}\text { Well-blended } \\
\text { meaty and mung } \\
\text { bean aroma }\end{array}$ & $7.97^{\mathrm{a}}$ & $\begin{array}{l}\text { Well-blended } \\
\text { meaty and mung }\end{array}$ & $7.97^{a}$ \\
\hline $\begin{array}{l}\mathrm{T}_{4}-30 \% \\
\mathrm{MF}\end{array}$ & $\begin{array}{l}\text { Reddish } \\
\text { brown }\end{array}$ & $7.80^{\mathrm{abc}}$ & $\begin{array}{l}\text { Very perceptible } \\
\text { mung bean }\end{array}$ & $8.23^{a}$ & $\begin{array}{l}\text { Very perceptible } \\
\text { mung bean }\end{array}$ & $7.90^{\mathrm{a}}$ \\
\hline $\begin{array}{l}\mathrm{T}_{5}-40 \% \\
\mathrm{MF}\end{array}$ & $\begin{array}{l}\text { Reddish } \\
\text { brown }\end{array}$ & $7.53^{\mathrm{bc}}$ & $\begin{array}{l}\text { Well-blended } \\
\text { meaty and mung } \\
\text { bean aroma }\end{array}$ & $7.73^{\mathrm{a}}$ & $\begin{array}{l}\text { Well-blended } \\
\text { meaty and mung } \\
\text { bean }\end{array}$ & $7.73^{\mathrm{ab}}$ \\
\hline $\begin{array}{l}\mathrm{T}_{6}-50 \% \\
\mathrm{MF}\end{array}$ & $\begin{array}{l}\text { Reddish } \\
\text { brown }\end{array}$ & $7.40^{\circ}$ & $\begin{array}{l}\text { Well-blended } \\
\text { meaty and mung } \\
\text { bean aroma }\end{array}$ & $7.63^{a}$ & $\begin{array}{l}\text { Well-blended } \\
\text { meaty and mung } \\
\text { bean }\end{array}$ & $7.20^{\mathrm{b}}$ \\
\hline$p$-value & & 0.0129 & & 0.1301 & & 0.0076 \\
\hline
\end{tabular}

Means within a column having common letter-superscripts are not significantly different.

Hedonic Rating Scale: 1 - dislike extremely, 2 - dislike very much, 3 - dislike moderately, 4 - dislike moderately, 4 - dislike slightly, 5 either like nor dislike, 6 - like slightly, 7 - like moderately, 8 - like very much, 9 - like extremely 
Quality and acceptability of burger patty

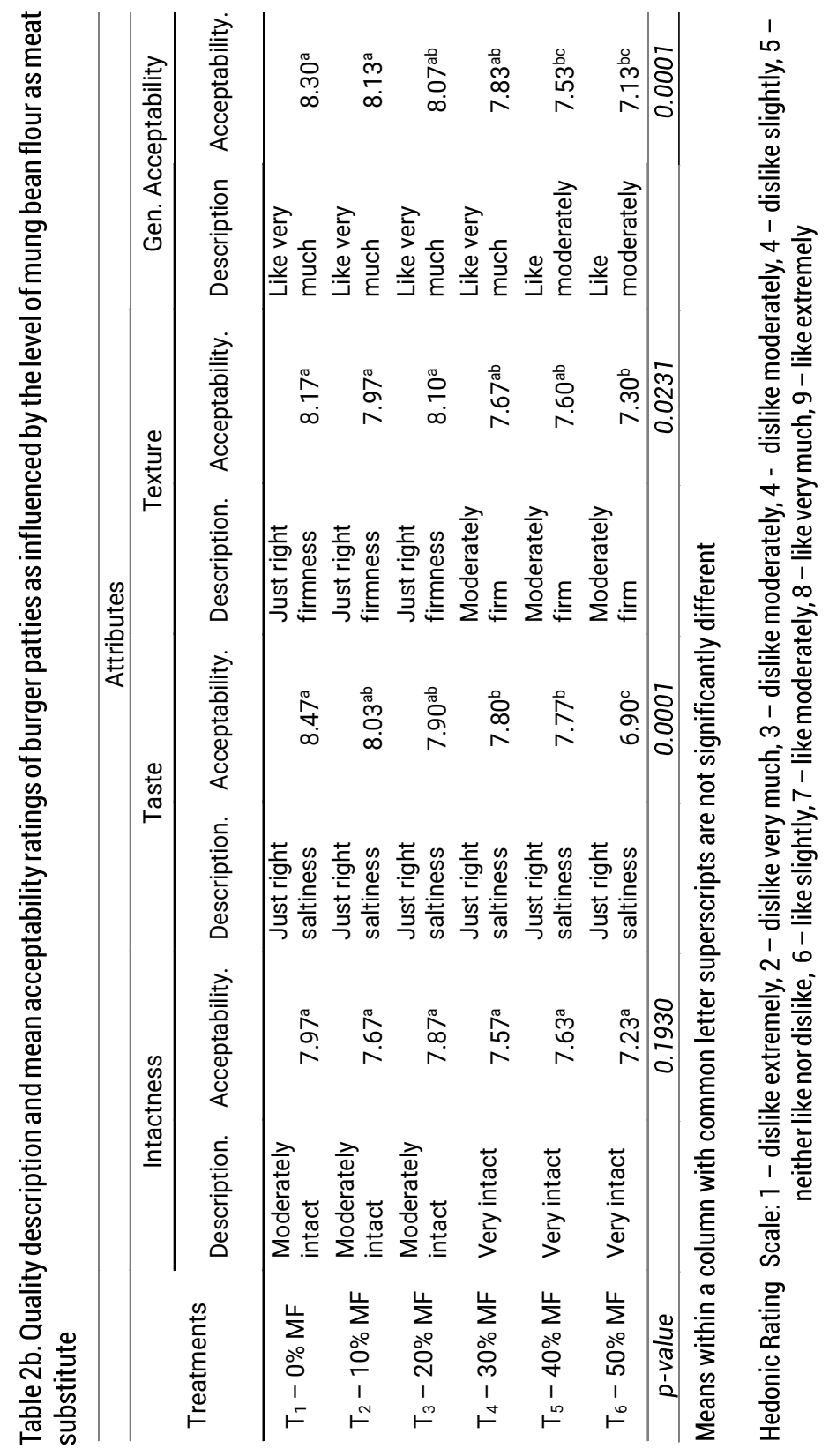


Morbos et al

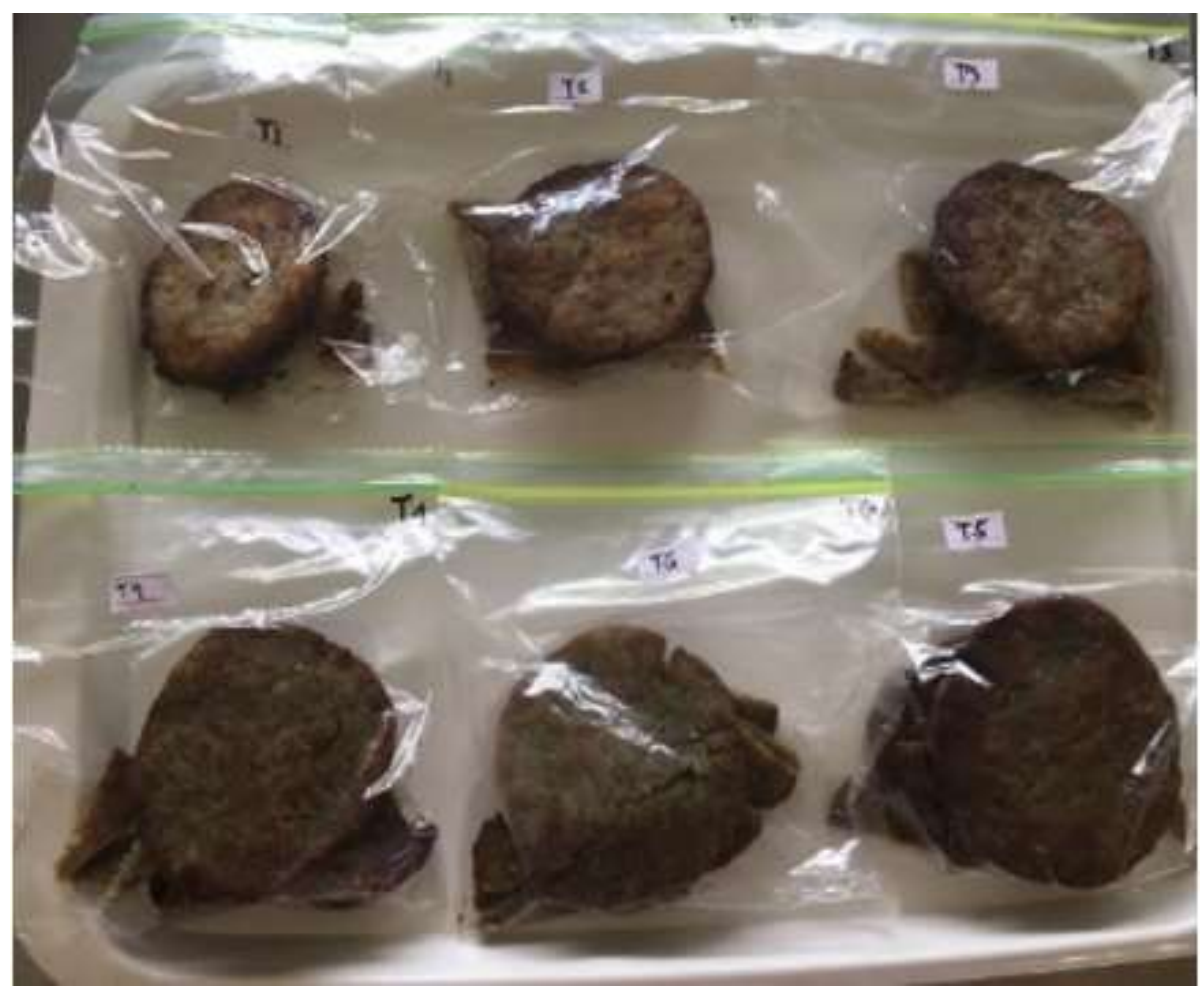

Figure 7. Cooked burger patty

Table 2a shows a significant variation $(P<0.05)$ in color acceptability of the patty among the different treatments. T1 was the highest while T6 the lowest. T1 was rated "like very much" while T6 as "like moderately'. Other treatments (T2 to T5) were not significantly different from each other. This means that the levels (10-40\%) of mung bean flour incorporated had no significant effect on the color attribute of the formulated burger.

\section{Aroma}

The aroma of the burger patty was perceived by the panelists as "slightly perceptible mung bean" to" very perceptible mung bean". Table 2a shows that "slightly perceptible mung bean aroma" was observed in T1, "very perceptible mung bean" in T2 and T4 and "well blended meaty and mung bean aroma" in T3, T5 and T6, which were influenced by mung bean powder incorporated in the mixture. This means that at higher levels of mung bean flour results to "well blended meaty and mung bean aroma".

In terms of aroma acceptability, no significant differences were observed among treatments (Table $2 a$ ). 
Quality and acceptability of burger patty

\section{Flavor}

Flavor is an important attribute of meat products that is derived from the ingredients incorporated. The flavor of the burger patty was perceived by the panelists as "slightly perceptible mung bean" to "well-blended meat and mung bean". $T_{1}$ was observed by the panelists to have "slightly perceptible mung bean", while, T2 and T4 were perceived to be very perceptible mung bean and T3, T5 and T6 were observed to have "well-blended meaty and mung bean flavor". The perceived flavor of T2 to T6 were mainly due to the greater amount of mung bean powder (10 and $50 \%$ ) added in the mixture. With respect to flavor acceptability, significant differences were observed among treatments (Table $2 a$ and Figure 10). T1 to T4 were significantly higher, which were rated by the panelists as "like very much", while T6 was lowest which was rated by the panelist as "like moderately".

\section{Intactness}

The panelists perceived the intactness of burger patty to be "moderately intact" to "very intact". T1 to T3 were observed to be "moderately intact, while T4 to T6 were perceived to be "very intact". Patty was found more compact at higher levels of mung bean flour (T4 to T6). In terms of intactness acceptability, no significant differences were noted among treatments. However, panelists rated T1 to T5 with "like very much", while T6 with "like moderately". Results showed that addition of mung bean flour as extender had no effect on the intactness of burger patties.

\section{Taste}

Table $2 \mathrm{~b}$ shows that panelists perceived cooked burger patties to have "just right saltiness" in all treatments. In terms of taste acceptability, significant differences were observed between treatments. $T_{1}$ was perceived to be significantly highest, which was rated as "like very much", while T6 the lowest. In the other treatments (T2 to T5), no significant effects were observed; however, they were all rated as "like very much" in a 9-point hedonic scale (Table 2b).

\section{Texture}

Texture is probably considered to be the most important attribute to the overall eating quality by average consumers (Chrystall 1994, Dransfield 1994). Sensory appreciation or judgment incorporates all the characteristics of the food. In this study, the texture of burger patty was perceived by the panelists as "just right firmness" to "moderately firm". T1 to T3 were observed to have just "right firmness", while T4 to T6 were "moderately firm". In terms of texture acceptability, significant effect was observed between treatments. T1 to T3 were significantly highest which was rated as "like very much" while T6 was the lowest and rated as "like moderately (Table 2b). 


\section{General Acceptability}

General acceptability corresponded to the overall acceptability of the product based on its attributes perceived by the senses of the taste panelists. General acceptability mean scores of burger patties in all treatments is presented in Table 2a. The results showed significant treatment effects, which T1 and T2 were significantly highest and were rated as "like very much" while T5 and T6 were the lowest, which were rated as "like moderately". The result implied that increasing the level of mung bean flour beyond $30 \%$ decreases acceptability of the product. The lowest acceptability of burger patty with high level of mung bean flour could be due to low fat content of the product replacing pork meat with mung bean flour which is less in fat content. The result is manifested to the lowest crude fat/ ether extract content of T6 (50\% MP) in the proximate analysis (Table 4). This explains that the fat level in the burger fatty affects the overall acceptability. Lipids make a significant contribution to the flavor of meats (Reineccius 1994) and consequently affects meat products, such as burger patty.

\section{Physicochemical Properties of Burger Patty}

Proximate Composition of Burger Patty. Table 3 shows the proximate composition of the different types of cooked burger patty. It can be gleaned that moisture content, ether extract and crude protein follow a similar pattern. Increasing the level of mung bean flour in burger patty resulted to a decreasing trend in chemical content, while dry matter had an increasing trend.

In terms of moisture content, $T_{1}$ had the highest moisture content, while $T_{5}$ the lowest. In terms of crude protein content, $\mathrm{T}_{0}$ had the highest crude protein content, while $\mathrm{T} 6 \mathrm{had}$ the lowest, indicating that $\mathrm{T}_{1}$ (pure meat) is rich in protein content. The result showed that with increasing level of mung bean flour, the protein content of the patty decreases. On the other hand, fat content of the burger patty follows a similar trend with that of the crude protein. The fat content of burger patty was higher in $\mathrm{T}_{1}$ ( $0 \%$ mung bean flour) while $\mathrm{T}_{2}$ to $\mathrm{T}_{5}$ (with mung bean) had a decreasing fat content. The high fat content of $T_{1}$ (pure meat) contributed greatly to the fat content of burger patties. The results of the study indicated that the addition of mung bean did not drastically change the nutrient content of the patty. However, it reduced the moisture, crude protein and crude fat.

Table 3. Proximate composition of burger patty with mung bean flour

\begin{tabular}{lcccc}
\hline Treatment & $\begin{array}{c}\text { Moisture } \\
\text { Content (\%) }\end{array}$ & $\begin{array}{c}\text { Dry Matter } \\
(\%)\end{array}$ & $\begin{array}{c}\text { Crude } \\
\text { Protein (\%) }\end{array}$ & $\begin{array}{c}\text { Ether Extract } \\
(\%)\end{array}$ \\
\hline T1 - 0\% MF & 47.42 & 52.48 & 32.94 & 38.86 \\
T2 - 10\% MF & 48.40 & 51.60 & 29.76 & 33.96 \\
T3 - 20\% MF & 47.55 & 52.45 & 28.42 & 31.35 \\
T4 - 30\% MF & 43.00 & 57.00 & 25.62 & 22.70 \\
T5 - 40\% MF & 42.28 & 57.72 & 23.34 & 21.82 \\
T6 - 50\% MF & 43.29 & 56.71 & 22.95 & 20.44 \\
\hline
\end{tabular}


Quality and acceptability of burger patty

\section{Cooking Loss, Diameter Shrinkage, Thickness Expansion and oil absorbed of Cooked Burgers}

Cooking loss, diameter shrinkage, thickness expansion and oil absorbed by cooked burger patties are shown in Table 3. Cooking loss results revealed significant differences among treatments. T1 and T2 were highest in terms of cooking loss, while T3 to T6 had no significant differences. Weight loss occurred during frying mainly due to moisture evaporation and dripping of melted fat (Alakali et al 2010, Mansour \& Khalil 1997). T1 and T2 had the highest cooking loss among the samples $(\mathrm{P}<0.05)$, likely because more fluid was lost during cooking due to the higher fat content as supported in the proximate analysis result. This result agreed with what Suman and Sharma (2003) reported. Cooking loss was positively correlated with fat content. Fat content greatly influenced drip loss. The diameter shrinkages of burger patty ranged from 19.8 to $5.5 \%$. Statistical analysis showed significant differences among treatments $(P>0.05)$. T1 to T3 had significantly higher shrinkage in patty diameter than T4 to T6. This means that patty with greater amount of mung bean flour from 40 to $50 \%$ (T4 to T6) had lower diameter shrinkage. Diameter size is an important parameter because burgers are mainly served with burger buns, thus must be comparable with bun size. Burgers shrink during cooking due to meat protein denaturation and fluid (moisture and fat) loss. Volume reduction is reflected mainly by diameter reduction, not by reduction of thickness (Pan \& Singh 2001). In this study, diameter shrinkage was positively correlated with cooking loss and fat content. Thickness expansion and oil absorbed after frying were found to have no significant differences among treatments.

Table 4. Cooking loss, diameter shrinkage and oil absorbed of burger patties with mung bean flour as substitute

\begin{tabular}{lcccc}
\hline Treatment & $\begin{array}{c}\text { Cooking } \\
\text { loss } \\
(\%)\end{array}$ & $\begin{array}{c}\text { Diameter } \\
\text { shrinkage (\%) }\end{array}$ & $\begin{array}{c}\text { Thickness } \\
\text { Expansion (\%) }\end{array}$ & $\begin{array}{c}\text { Oil absorbed } \\
(\%)\end{array}$ \\
\hline T1 - 0\% MF & $37.830^{\mathrm{a}}$ & $19.833^{\mathrm{a}}$ & $23.29^{\mathrm{b}}$ & $5.5329^{\mathrm{a}}$ \\
T2 - 10\% MF & $22.557^{\mathrm{a}}$ & $17.557^{\mathrm{a}}$ & $27.81^{\mathrm{b}}$ & $5.5556^{\mathrm{a}}$ \\
T3 - 20\% MF & $19.253^{\mathrm{b}}$ & $11.971^{\mathrm{a}}$ & $38.29^{\mathrm{a}}$ & $10.000^{\mathrm{a}}$ \\
T4 - 30\% MF & $14.550^{\mathrm{b}}$ & $8.5694^{\mathrm{b}}$ & $25.24^{\mathrm{b}}$ & $15.556^{\mathrm{a}}$ \\
T5 - 40\% MF & $16.963^{\mathrm{b}}$ & $10.321^{\mathrm{b}}$ & $27.89^{\mathrm{b}}$ & $5.5556^{\mathrm{a}}$ \\
T6 - 50\% MF & $14.900^{\mathrm{b}}$ & $5.5329^{\mathrm{b}}$ & $35.33^{\mathrm{a}}$ & $12.222^{\mathrm{a}}$ \\
\hline
\end{tabular}

a, b Different superscript letter in the same column indicate significant differences among samples $(P<0.05)$

Production Cost of Burger Patty. Table 5 shows the production cost of burger patty with mung bean flour. T1 had the highest, while T6 the lowest. Increasing level of mung bean flour reduces production cost and the break-even price per $45 \mathrm{~g}$ of patty. 
Table 5. Production cost of burger patties with mungbean flour

\begin{tabular}{lcc}
\hline Treatments & Cost $(\mathrm{PhP})$ & Price/per $45 \mathrm{~g}(\mathrm{PhP})$ \\
\hline T1 $-0 \% \mathrm{MF}$ & 171.97 & 10.74 \\
T2 - 10\% MF & 163.22 & 10.20 \\
T3 - 20\% MF & 154.47 & 9.65 \\
T4 - 30\% MF & 85.72 & 5.36 \\
T5 - 40\% MF & 76.97 & 4.81 \\
T6 -50\% MF & 68.22 & 4.26 \\
\hline
\end{tabular}

\section{CONCLUSIONS}

Burger patties from pork can be successfully substituted with mung bean with significant effects on color, flavor, taste, texture and overall acceptability. Considering those attributes, substitution of up to $30 \%$ is comparable to all-meat burger patty. However, proximate composition in terms of crude protein and fat/ether extract contents are comparable only to the control (all-meat) up to $20 \%$ level of substitution. The use of cheap legume (mung bean flour) as meat substitute can enhance the physical quality of the formulated patties by decreasing the cooking loss. There is also a significant reduction in cost of the products developed without compromising quality that ensures the nutritional security of people in developing countries especially in the rural areas.

\section{RECOMMENDATIONS}

Across all sensory measures and acceptability, protein and fat content, and shrinkage and cooking loss, the $30 \%$ substitution of meat with mung bean flour in burger patty is highly recommended.

\section{ACKNOWLEDGMENT}

The authors acknowledge with gratitude the funding support of ESSU-Salcedo and the Department of Food Science and Technology of the Visayas State University for the conduct of the sensory evaluation and laboratory analysis.

\section{REFERENCES}

Association of Official Agricultural Chemists.1985. Official Methods of Analysis. Association of official analytical Chemists (14th edn). Washington, D.C

Aruna V and Prakash V. 1993. Functional properties of the total protein of sun-flour seed. Effect of physical and chemical treatments. Journal of Agricultural Food Chemistry $41(1): 18-23$

Bender A. 1992. Meat and meat products in human nutrition in developing countries. Food and Agriculture Organization of the United Nations (FAO), Food 
Quality and acceptability of burger patty

and Nutrition Paper 53, Italy, Rome.http://www.fao.org/docrep/t0562e/t0562 e00.htm

Bhat ZF and Pathak V. 2009. Effect of mung bean (Vigna radiata) on quality characteristics of oven roasted chicken seekh kababs. Fleischwirtschaft International 6:58-60

Chrystall B. 1994. Meat texture measurement. In Pearson AM and Dutson TR (eds) Quality Attributes and their Measurement in Meat, Poultry and Fish Products (pp316-336). Black Academic \& Professional, UK

Dransfield E. 1994. Tenderness of meat, poultry and fish. In Pearson AM and Dutson TR (eds) Quality Attributes and their Measurement in Meat, Poultry and Fish Products (pp289-315). Black Academic \& Professional. UK

Dzudie T, Joel Scher J \& Hardy J. 2002. Common bean flour as an extender in beef sausages. Journal of Food Engineering 52(2):143-147

Egbert WR, Huffman DL, Chen CM \& Dylewski DP. 1991. Development of low - fat ground beef. Food Technology 45(6):64-66

Gill JL. 1981. Design and Analysis of Experiments in the Animal and Medical Sciences (2nd edn). ISBN. USA

Gujral HS, Kaur A, Singh N \& Sodhi SN. 2002. Effect of liquid whole egg, fat and textured soy protein on the textural and cooking properties of raw and baked patties from goat meat. Journal of Food Engineering 53(4):377-385

Jimenez-Colmenero F, Carballo J \& Cofrade S. 2001. Healthier meat and meat products: Their role as functional foods. Meat Science 59(1):5-13

Khalid EK, Babiker EF \& Eltinay AH. 2003. Solubility and functionality properties of sesame seed protein as influenced by $\mathrm{pH}$ and/or salt concentration. Food Chemistry 82(3):361-366

Khalil A. 2006. Nutritional improvement of an Egyptian breed of mung bean by probiotic lactobacilli. African Journal of Biotechnology 5(2):206-212

Lawrie RA. 1979. Meat Science (3rd edn). Pergamon Press, New York

Liu K. 2000. Expanding soy bean food utilization. Food Technology 54(7):46-58

Modi VK, Mahendrakar NS, Rao DN \& Sachindra NM. 2004. Quality of buffalo meat burger containing legume flours as binders. Meat Science 66(1):143-149

Nag S, Sharma BD \& Kumar S. 1998. Quality attributes and shelf life of chicken nuggets extended with rice flour. Indian Journal of Poultry Science 33(2):182186

Nestle M. 1999. Animal v. plant foods in human diets and health: Is the historical record unequivocal. The Proceedings of the Nutrition Society 58(2):211-218. PMID:10466159

Reineccius G. 1994.Flavor and aroma chemistry. Advance in Meat Research 9:184185

Roberts LH. 1974. Sausage emulsion-functionality of non-meat proteins during emulsification. In proceedings, Meat Industry Conference, American Meat Institute, Washington, D.C

Serdarouglu M and Degimencioglu 0. 2004. Effect of fat level (5, 10 and 20\%) and corn flour (0,2 and 4\%) on some properties of Turkish type meatballs (koefte). Meat Science 68(2):291-296

Varnam AL and Sutherland JP. 1995. Meat and Meat Products 3:2-150. Chapman and Hall 2-6 Boundary Row. London.

http://www.fao.org/docrep/010/ai407e/AI407E.htm

http://www.fao.org/docrep/t0562e03.htm

canada2017appalication@gmail.com oct31 